\title{
Drawing analysis in the assessment of patients with neurodegenerative diseases
}

\section{Figure 1 Copying vs spontaneous drawing by a patient with advanced early-onset Alzheimer disease}

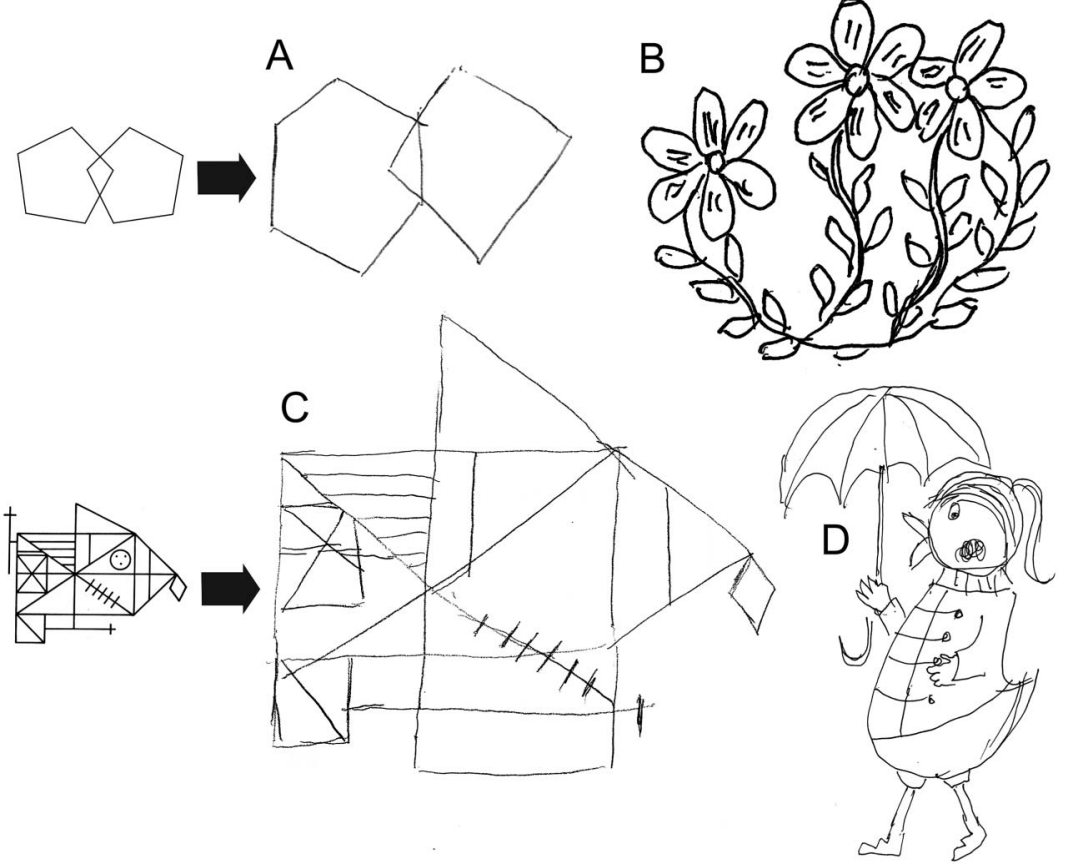

(A) Pentagon drawing from Mini-Mental State Examination (the patient scored 7/30). (B) Flower drawing to command (reminiscent of baubles she decorated professionally). (C) Rey Complex Figure copy with spatial distortions. (D) Spontaneous duck character drawing. At home, the patient used to produce duck character drawings in a perseverative manner.

A drawing may elucidate a cognitive profile in neurodegenerative conditions, as illustrated here. A 64-year-old woman with early-onset Alzheimer disease exhibited impaired visual perception (poor copying), which contrasted with good access to acquired constructional representations or motor routines (well-constructed spontaneous drawings) (figure 1).

A 60-year-old patient with frontotemporal dementia and parkinsonism linked to chromosome 17 with P301L MAPT mutation (11 years after onset), with executive dysfunction and hemispatial neglect, ${ }^{1}$ produced a drawing with well-delineated, but markedly disconnected, internal details (figure 2). Thus, in this case, exploded drawing might be linked to the executive deficits, rather than solely to impaired visuoperception. ${ }^{2}$

Emilia J. Sitek, $M A, P h D$, Ewa Narożanska, $M D, P h D$, Seweryna Konieczna, $M D, M A, P h D$,

Bogna Brockhuis, MD, PhD, Dariusz Wieczorek, MA, PhD, Zbigniew K. Wszolek, MD, PhD,

Jarostaw Stawek, $M D, P h D$

From the Medical University of Gdansk (E.J.S., S.K., B.B., D.W., J.S.); Copernicus PL St. Adalbert Hospital (E.J.S., E.N., J.S.), St. Adalbert Hospital, Gdansk, Poland; and Mayo Clinic (Z.K.W.), Jacksonville, FL.

Author contributions: E.J. Sitek: study concept and design, acquisition of data, manuscript draft. E. Narozanska: acquisition of data.

S. Konieczna: data analysis. B. Brockhuis: data analysis. D. Wieczorek: data analysis, graphics. Z.K. Wszolek: study supervision.

J. Slawek: study supervision, revision of the manuscript.

Study funding: No targeted funding reported.

Disclosure: E. Sitek is a consultant of Cogstate Ltd. and was supported by the scholarship for young scientists awarded by Polish Ministry of Science and Higher Education while preparing the manuscript. E. Narożańska, S. Konieczna, B. Brockhuis, and D. Wieczorek report no disclosures relevant to the manuscript. Z. Wszolek is partially supported by the NIH/NINDS P50 NS072187, NIH/NIA (primary) 
Age (years/months)

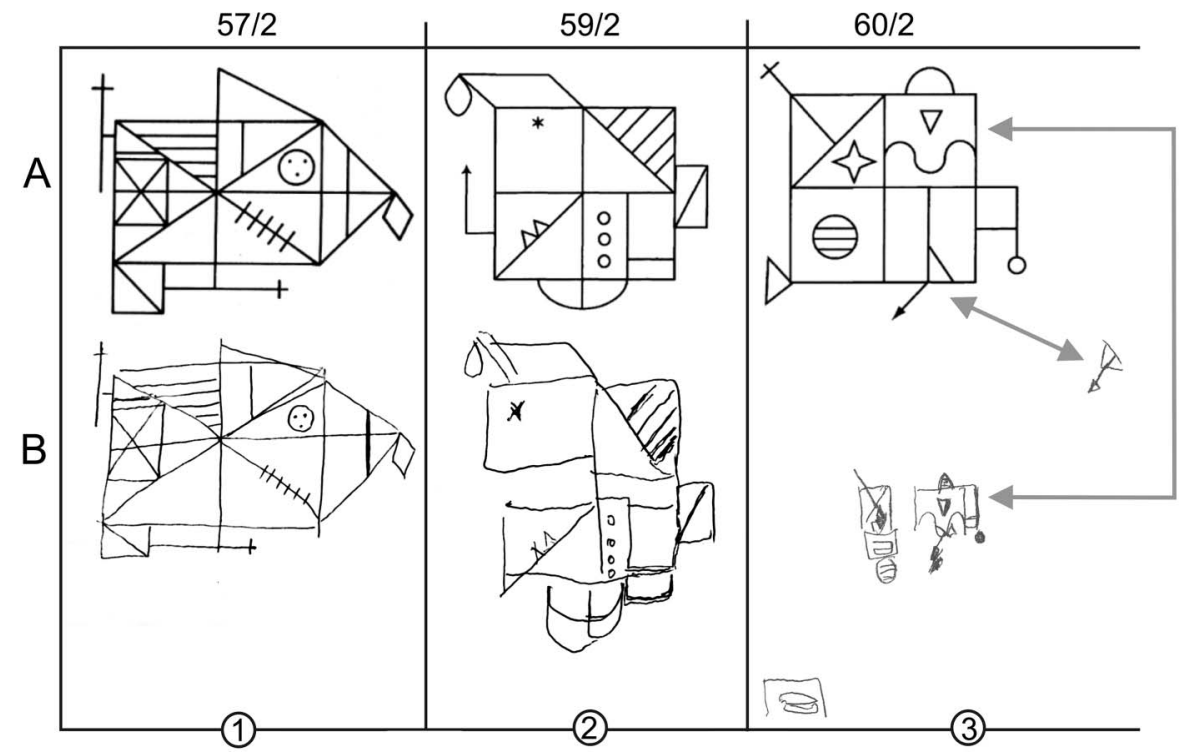

(A) Model figures. (B) The patient's copies. In B3, dramatically misplaced details correspond to the exploded drawing characteristics. However, the internal details are precisely copied, which is not typical for simultanagnosia. The left side omissions are due to hemispatial neglect. The 2 most outstanding disjointed details are marked with arrows.

and NIH/NINDS (secondary) 1U01AG045390-01A1, Mayo Clinic Center for Regenerative Medicine, Mayo Clinic Center for Individualized Medicine, Mayo Clinic Neuroscience Focused Research Team (Cecilia and Dan Carmichael Family Foundation, and the James C. and Sarah K. Kennedy Fund for Neurodegenerative Disease Research at Mayo Clinic in Florida), gift from Carl Edward Bolch, Jr., and Susan Bass Bolch, and The Sol Goldman Charitable Trust. He serves as co-Editor-in-Chief of Parkinsonism and Related Disorders and as Associate Editor of European Journal of Neurology. J. Slawek is a co-editor of Polish Journal of Neurology and Neurosurgery Journal and a medical consultant to Roche, Allergan, Ipsen, GE, Merz, UCB. Go to Neurology.org for full disclosures.

Correspondence to Dr. Sitek: emiliasitek@gumed.edu.pl

1. Sitek EJ, Narozanska E, Barczak A, et al. Agraphia in patients with frontotemporal dementia and parkinsonism linked to chromosome 17 with P301L MAPT mutation: dysexecutive, aphasic, apraxic or spatial phenomenon? Neurocase 2014;20: 69-86.

2. McMonagle P, Kertesz A. Exploded drawing in posterior cortical atrophy. Neurology 2006;67:1866.

\section{WriteClick ${ }^{\circledR}$ rapid online correspondence}

Have a comment on a recent Neurology ${ }^{\circledR}$ article you would like to share? Now it is easier and more convenient. Neurology.org has launched WriteClick on the home page and sidebars of each article to encourage remarks and debate among users.

WriteClick is restricted to comments about studies published in Neurology within the last eight weeks.

Learn more at Neurology.org/letters 


\section{Neurology}

Drawing analysis in the assessment of patients with neurodegenerative diseases Emilia J. Sitek, Ewa Narozanska, Seweryna Konieczna, et al. Neurology 2017;88;218-219

DOI 10.1212/WNL.0000000000003496

This information is current as of January 9, 2017

Updated Information \& Services

References

Subspecialty Collections

Permissions \& Licensing

Reprints including high resolution figures, can be found at: http://n.neurology.org/content/88/2/218.full

This article cites 2 articles, 1 of which you can access for free at: http://n.neurology.org/content/88/2/218.full\#ref-list-1

This article, along with others on similar topics, appears in the following collection(s):

Alzheimer's disease

http://n.neurology.org/cgi/collection/alzheimers_disease Assessment of cognitive disorders/dementia

http://n.neurology.org/cgi/collection/assessment_of_cognitive_disorder S_dementia

Cognitive neuropsychology in dementia

http://n.neurology.org/cgi/collection/cognitive_neuropsychology_in_de mentia

Frontotemporal dementia

http://n.neurology.org/cgi/collection/frontotemporal_dementia

Information about reproducing this article in parts (figures,tables) or in its entirety can be found online at:

http://www.neurology.org/about/about_the_journal\#permissions

Information about ordering reprints can be found online:

http://n.neurology.org/subscribers/advertise

Neurology ${ }^{\circledR}$ is the official journal of the American Academy of Neurology. Published continuously since 1951, it is now a weekly with 48 issues per year. Copyright (C 2017 American Academy of Neurology. All rights reserved. Print ISSN: 0028-3878. Online ISSN: 1526-632X.

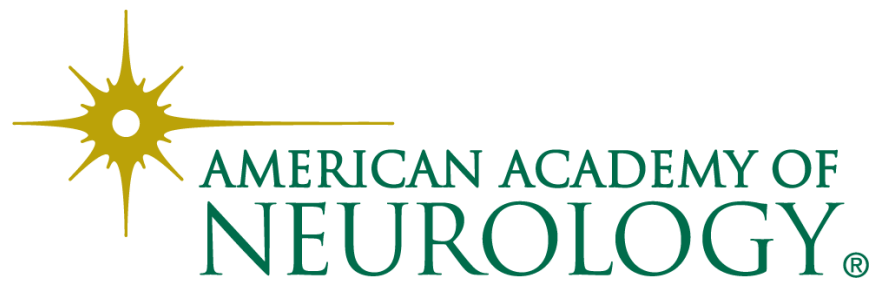

